\title{
Effects of different fertilization practices on the carotene content of carrot
}

\author{
AINO-MAIJA EVERS \\ Kemira Oy, Espoo Research Centre, Luoteisrinne 2, \\ SF-02270 Espoo, Finland
}

\begin{abstract}
The effects of different fertilization practices on the carotene content of carrot cv. Nantes Duke Notabene $370 \mathrm{~Sv}$ were studied in field experiments in southern Finland. Unirrigated and irrigated placement and broadcast fertilization, NPK fertirrigations without basic fertilization, NPK fertirrigations with NPK basic fertilization, and PK placement with $\mathrm{N}$ fertirrigations were compared. Further, single application was compared to split applications. Carotene determinations were done at harvest in 1985 and 66,88 and 121 (at harvest) days from sowing in 1986 . The results were studied by contrast analysis.

Weather conditions had a strong effect on the carotene content and in both years the carotene content increased with the length of the growing season. At harvest in 1985, PK placement with $\mathrm{N}$ fertirrigations had a tendency to yield a higher carotene content than did broadcast fertilization, irrigated single application, and NPK fertirrigations. The carotene content was higher when $\mathrm{P}$ and $\mathrm{K}$ were placement fertilized as compared to treatments where $\mathrm{P}$ and $K$ were broadcast fertilized or fertirrigated $(p=0.1)$. At the first sampling date in 1986 , fertilization increased the carotene content $(\mathrm{p}=0.1)$. $\mathrm{PK}$ placement with $\mathrm{N}$ fertirrigations had a tendency to increase the carotene content as compared to placement fertilization, single application and irrigated single application. At the second sampling date and at harvest in 1986 no statistically significant differences could be found.

The results indicate that the placement of PK-fertilizer or NPK-fertilizer was favourable to carotene production. Besides the fertilization experiment, samples from two organically cultivated fields were collected to obtain data concerning organically cultivated carrots.
\end{abstract}

Index words: carrot, placement fert., broadcast fert., fertirrigation, carotene, organic cultivation

\section{Introduction}

Carrot (Daucus carota L.) contains many carotenoids, mainly tetraterpenes of the isoprenoid group. About $60 \%$ of the total carotene content in carrot is $\beta$-carotene (Gabelman 1974). The variation in carotene content is dependent on genotype (GABELMAN 1974) and climate (Simon et al. 1982). The developmental stage of a plant (BANGA et al. 1963, Phan \& Hsu 1973, Fritz \& Habben 1975) and temperatures during the growing 
season (BARNES 1936, BANGA et al. 1955) also have a considerable effect on the carotene content. In addition, soil moisture (BANGA \& DE BruYN 1964, Dragland 1978), the intensity of photosynthesis, shoot size, and plant density (BANGA \& DE BRUYN 1964) affect the carotene content of carrots.

The literature contains reports about the influence of macronutrients on the carotene content the results of which are contradictory. Freeman \& Harris (1951) and Habben (1973) found that increasing the amounts of nitrogen increased the carotene content. On the other hand, Dragland (1978) reported that increasing nitrogen amounts did not affect the carotene content, and SouthardS \& Miller (1962) obtained the highest carotene contents with low nitrogen levels. The same contradiction has been observed for potassium. In some studies, increasing amounts of potassium had no significant influence on carotene content (GALlaGHER 1966, HabBen 1973), whereas others (SoutHARDS \& Miller 1962) reported that high potassium and magnesium levels increased the amount of carotene in carrots. NILSSON (1979) found no differences in carotene contents resulting from fertilizer levels or the use of organic versus inorganic fertilizers. The effects of different fertilization practices and the split application of nutrients have been studied very scarcely. The aim of the present study was to investigate whether unirrigated or irrigated placement and broadcast fertilization, fertirrigation and their combinations as well as the split application of nutrients affect the carotene content of carrots.

\section{Material and methods}

\section{Field experiment}

The field experiment was done on the Kotkaniemi Experimental Farm of Kemira Oy. in Vihti, southern Finland, in the summers of 1985 and 1986. Carrot cv. Nantes Duke Notabene $370 \mathrm{~Sv}$ was grown as described by EvERS (1988). The experiment was arranged in four

Table 1. The fertilization treatments

\begin{tabular}{|c|c|c|c|c|c|c|}
\hline \multirow{2}{*}{\multicolumn{2}{|c|}{ Treatment }} & \multirow{2}{*}{$\begin{array}{l}\text { Number and time } \\
\text { of fertilizer } \\
\text { applications }\end{array}$} & \multicolumn{3}{|c|}{$\begin{array}{l}\text { Macronutrient amounts } \\
\text { in } 1986^{3} \mathrm{~kg} / \mathrm{ha}\end{array}$} & \multirow{2}{*}{$\begin{array}{c}\text { Irrigation water } \\
\text { amounts in } 1985 \\
\text { and } 1986 \\
\text { mm }\end{array}$} \\
\hline & & & $\mathbf{N}$ & $\mathrm{P}$ & K & \\
\hline \multirow[t]{3}{*}{ No } & fertilization & & & & & \\
\hline & No irrigation & 0 & 0 & 0 & 0 & 0 \\
\hline & Irrigation & 0 & 0 & 0 & 0 & $3 \times 10$ \\
\hline \multirow[t]{3}{*}{ NPK } & placement & & & & & \\
\hline & No irrigation & 1 before sowing & 80 & 35 & 133 & 0 \\
\hline & Irrigation & 1 before sowing & 80 & 35 & 133 & $3 \times 10$ \\
\hline \multirow[t]{3}{*}{ NPK } & broadcast & & & & & \\
\hline & No irrigation & 1 before sowing & 80 & 35 & 133 & 0 \\
\hline & Irrigation & 1 before sowing & 80 & 35 & 133 & $3 \times 10$ \\
\hline \multirow[t]{3}{*}{ NPK } & fertirrigations & & & & & \\
\hline & Without basic fertilization & 3 during season & 80 & 29 & 160 & $3 \times 10$ \\
\hline & Half the NPK basic fertilization' & $\begin{array}{l}1 \text { before sowing and } \\
3 \text { during season }\end{array}$ & 80 & 32 & 142 & $3 \times 10$ \\
\hline \multirow[t]{3}{*}{ PK } & placement $^{2}$ & 1 before sowing and & 81 & 56 & 133 & $3 \times 10$ \\
\hline & $3 \mathrm{~N}$-fertirrigations & 3 during season & & & & \\
\hline & $4 \mathrm{~N}$-fertirrigations & $\begin{array}{l}1 \text { before sowing and } \\
4 \text { during season }\end{array}$ & 155 & 56 & 133 & $4 \times 10$ \\
\hline
\end{tabular}

1 Half of the nutrients were given by basic placement fertilization and half by NPK fertirrigations.

2 Phosphorus and potassium were given by basic placement fertilization and nitrogen by fertirrigations.

3 The nutrient amounts were $30 \%$ bigger in 1985 than in 1986. 
randomized blocks, with ten treatments per block and plots of $25 \mathrm{~m}^{2}$ (Table 1).

\section{Determination of carotene}

The carrot samples for the determination of carotene were collected on September 30, 1985 (117 days from sowing) and August 12, 1986, on September 3, 1986 and October 6, 1986 (66, 88 and 121 days from sowing, respectively). Six consecutive carrots were sampled from each plot, from a randomized place, and two analyses were made for each sample. In 1985 samples were collected from two blocks, in 1986 from four blocks. Carotene was determined by high-performance liquid chromatography (HPLC) on SPHERISORB 10 ODS $2250 \times 4.6 \mathrm{~mm}$ I.D. column, a bonded octadecylsilane stationary phase with visible photometric detection at wavelength $450 \mathrm{~nm}$ (LANGer 1976). This method measures the added $\alpha$ and $\beta$ carotene content. In the text it is termed carotene for short. 60 grams of fresh carrot tissue was crushed in a blender containing $100 \mathrm{ml} \mathrm{CH}_{2} \mathrm{Cl}_{2}$ and was mixed for 10 minutes, filtered and analyzed immediately by HPLC. The samples were protected from light and oxygen because these can destroy carotene. The data was studied statistically by contrast analysis (STEel \& TORRIE 1980).

\section{Organically cultivated carrots}

Simultaneously with those for the fertilization experiments, samples from two organically cultivated fields were collected. These organically cultivated carrots were grown with the same seed material, but the geographical locations (Varkaus and Rantasalmi) and soil characteristics differed from those of the fertilization experiments. In any case, these samples gave information of organically cultivated carrots. The compost and soil analyses as well as the amounts of compost used are given in a previous study (Evers 1988).

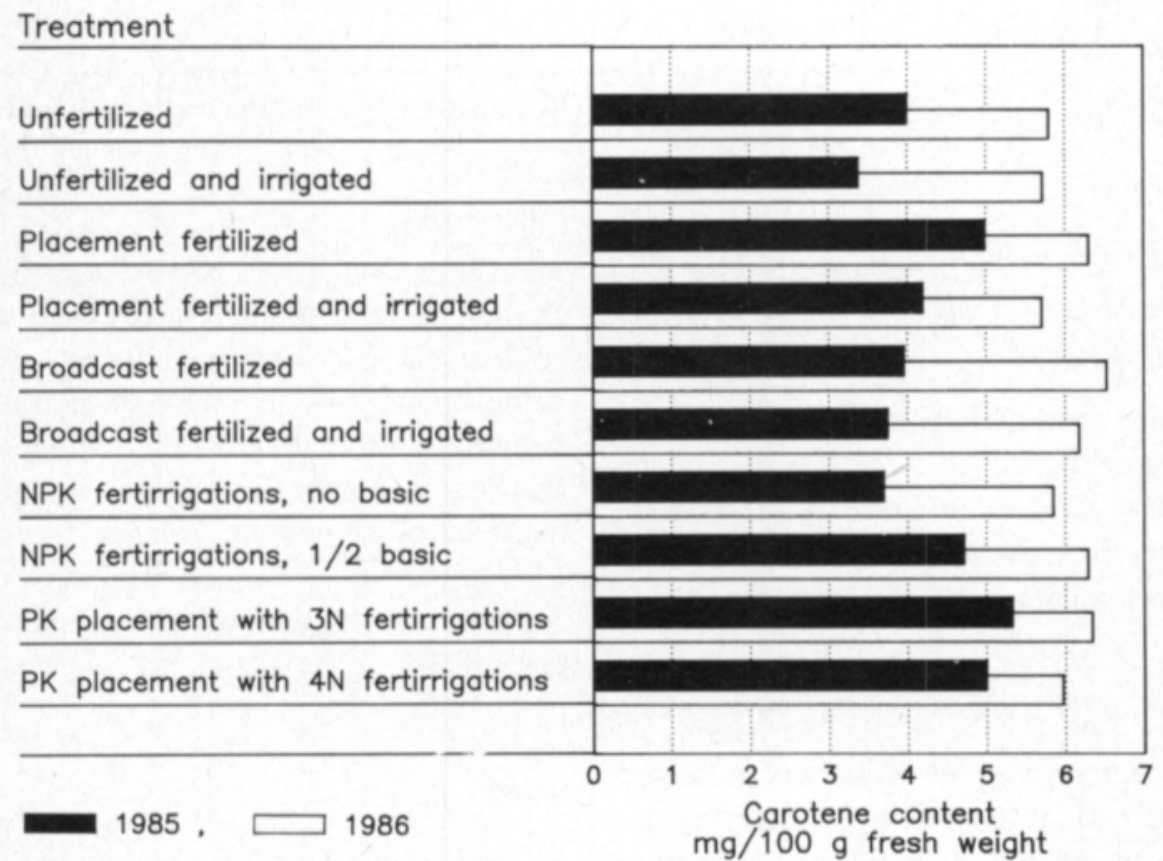

Fig. 1. The effect of different fertilization practices on the carotene content of carrots at harvest in 1985 and 1986. 

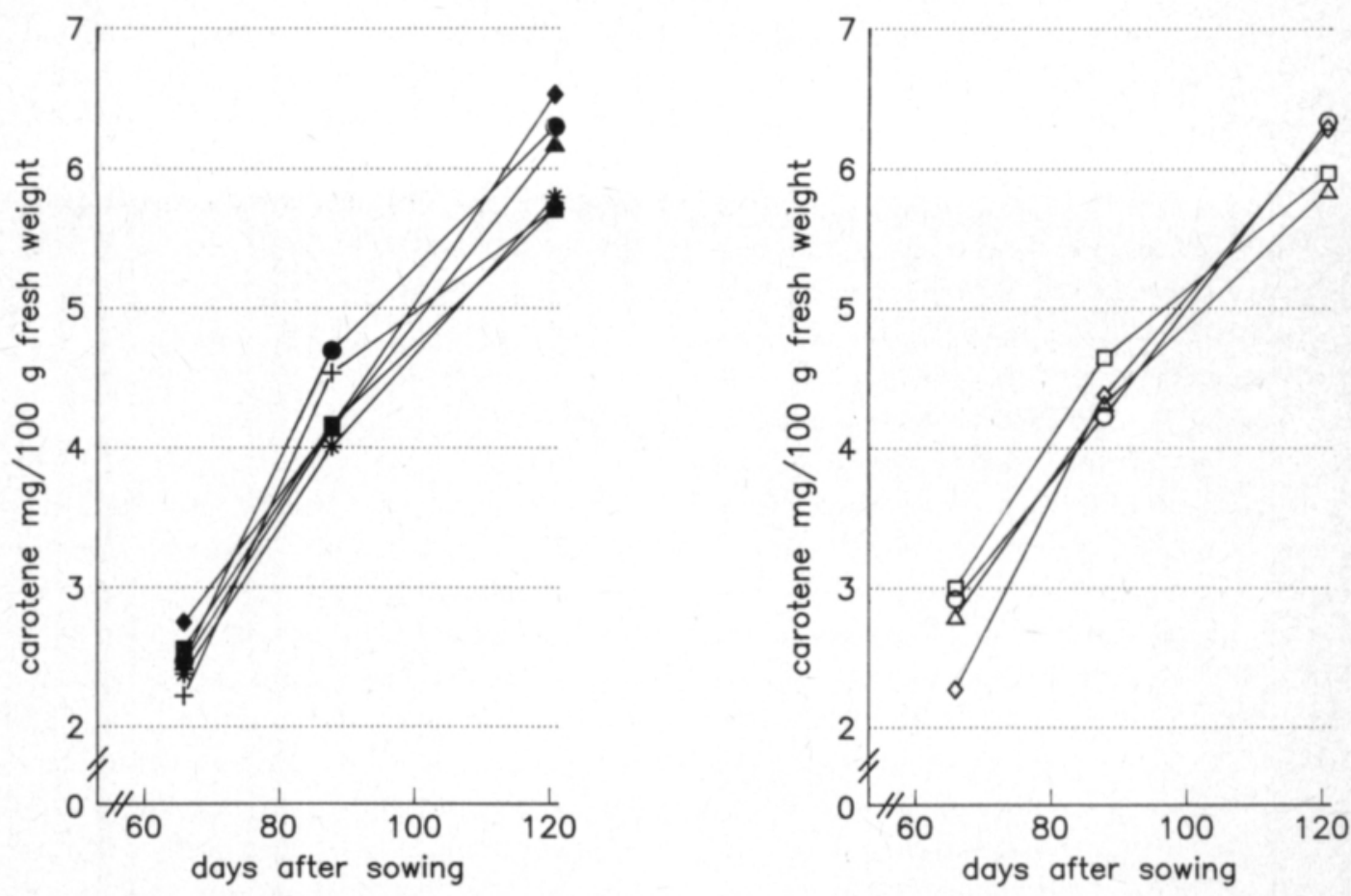

\begin{tabular}{|ll|}
\hline * Unfertilized & $\triangle N P K$ fertirrigations, no basic \\
+ Unfertilized and irrigated & $\diamond$ NPK fertirrigations, 1/2 basic \\
& \\
- Placement fertilized & $\circ$ PK placement with $3 N$ fertirrigations \\
- Broadcast fertilized & $\square$ PK placement with $4 \mathrm{~N}$ fertirrigations \\
- Broadcast fertilized and irrigated &
\end{tabular}

Fig. 2. The effect of different fertilization practices on the development of the carotene content of carrots in 1986.

\section{Results}

\section{Weather conditions}

Weather conditions had a strong effect on the carotene content of carrots. The carotene contents of carrots cultivated in 1985 were lower than in 1986 irrespective of the fertilization treatments $\left(\mathrm{p}<0.001^{* * *}\right)$ (Fig. 1).

\section{Developmental stage}

The carotene content of carrots increased with the length of the growing season (Fig. 2). At the first sampling date, 66 days from sowing, the carrots were about $10 \mathrm{~cm}$ long, with an average weight per carrot of 27.0 grams. In these young and small carrots, the carotene content was low, the average for all treatments being $2.6 \mathrm{mg} / 100 \mathrm{~g}$ fresh weight (FW). At the second sampling date, 88 days from sowing, the average weight per carrot was $76.5 \mathrm{~g}$, the mean carotene content being $4.3 \mathrm{mg} / 100 \mathrm{~g}$ FW. At harvest, 121 days from sowing, the corresponding values were $106 \mathrm{~g}$ and $6.1 \mathrm{mg} /$ $100 \mathrm{~g} \mathrm{FW}$.

\section{Fertilization}

The statistical analysis method used in this study did not reveal any significant differences 
between fertilization practices or between unfertilized and fertilized treatments on level $\mathrm{p}<0.05$. At harvest in $1985, \mathrm{PK}$ placement with $\mathrm{N}$ fertirrigations had a tendency to yield a higher carotene content than did broadcast fertilization, irrigated single application, and NPK fertirrigation $(p=0.1)$. There was also a tendency for a higher carotene content when $\mathrm{P}$ and $\mathrm{K}$ were placement fertilized as compared to treatments where $P$ and $K$ were broadcast fertilized or fertirrigated $(p=0.1)$.

At first sampling date in 1986, fertilization increased the carotene content $(p=0.1)$. PK placement with $\mathrm{N}$ fertirrigations had a tendency to increase the carotene content as compared to placement fertilization, single application and irrigated single application $(p=0.1)$. At the second sampling date and at harvest in 1986 no statistically significant differences could be found.

In both years, four treatments gave good results (Fig. 1). These were placement fertilization, NPK fertirrigation with NPK basic fertilization and $\mathrm{PK}$ placement with $\mathrm{N}$ fertirrigations. In both years NPK fertirrigations without basic fertilization yielded a low carotene content. Broadcast fertilization gave con- tradictionary results in two years. As compared to the average carotene content of unfertilized treatments, placement fertilization increased the carotene content by $35 \%$ in 1985 and by $9 \%$ in 1986, NPK fertirrigations with NPK basic fertilization increased the carotene content by $28 \%$ in 1985 and by $9 \%$ in 1986, and $\mathrm{PK}$ placement with $3 \mathrm{~N}$ fertirrigations increased the carotene content by $44 \%$ in 1985 and by $10 \%$ in 1986 .

\section{Carotene yield}

The order of superiority for the treatments was roughly similar whether the carotene content was calculated on the basis of fresh matter (Fig. 1) or dry matter (Table 2). When the results were studied as the calculated carotene yield per hectare (Table 2), some differences were observed for 1986. Irrigated placement fertilization produced a relatively low carotene content, but the carotene yield calculated as $\mathrm{g} / \mathrm{ha}$ was very good. On the contrary, broadcast fertilization produced a surprisingly high carotene content, but the carotene yield calculated as $\mathrm{g} / \mathrm{ha}$ was low. The same was true for PK placement with $\mathrm{N}$ fertirrigations (Fig. 1, Table 2).

Table 2. The effect of different fertilization practices on the carotene content of carrots calculated on dry weight basis and as a carotene yield per hectare.

\begin{tabular}{|c|c|c|c|c|c|c|}
\hline \multirow[t]{2}{*}{ Treatments } & \multicolumn{3}{|c|}{$\begin{array}{l}\text { Carotene content } \\
\mathrm{mg} / 100 \mathrm{~g} \text { dry weight }\end{array}$} & \multicolumn{3}{|c|}{$\begin{array}{l}\text { Carotene yield } \\
\mathrm{g} / \mathrm{ha}\end{array}$} \\
\hline & 1985 & 1986 & $\overline{\mathrm{x}}$ & 1985 & 1986 & $\overline{\mathrm{x}}$ \\
\hline Unfertilized & 42.5 & 54.2 & 48.3 & 1620 & 2760 & 2190 \\
\hline Unfertilized and irrigated & 35.1 & 53.4 & 44.2 & 1190 & 2620 & 1900 \\
\hline Placement fertilized & 49.7 & 60.0 & 54.9 & 1850 & 3190 & 2520 \\
\hline Placement fertilized and irrigated & 43.7 & 55.6 & 49.7 & 1520 & 3230 & 2380 \\
\hline Broadcast fertilized & 42.4 & 61.6 & 52.0 & 1620 & 3150 & 2380 \\
\hline Broadcast fertilized and irrigated & 38.3 & 60.1 & 49.2 & 1060 & 2970 & 2020 \\
\hline NPK fertirrigations, without basic & 41.4 & 56.8 & 49.1 & 1190 & 3050 & 2120 \\
\hline NPK fertirrigations, half the basic & 50.5 & 60.2 & 55.3 & 1830 & 3460 & 2650 \\
\hline PK placement with $3 \mathrm{~N}$ fertirrigations & 55.4 & 58.8 & 57.1 & 2090 & 3070 & 2580 \\
\hline PK placement with $4 \mathrm{~N}$ fertirrigations & 50.4 & 56.7 & 53.5 & 1760 & 3140 & 2450 \\
\hline$\overline{\mathrm{x}}$ & 44.9 & 57.7 & 51.3 & 1570 & 3060 & 2320 \\
\hline Organically cultivated, location 1 & \multicolumn{3}{|c|}{66.7} & \multicolumn{3}{|c|}{3240} \\
\hline Organically cultivated, location 2 & \multicolumn{3}{|c|}{64.6} & \multicolumn{3}{|c|}{2570} \\
\hline$\overline{\mathrm{x}}$ & \multicolumn{3}{|c|}{65.6} & \multicolumn{3}{|c|}{2910} \\
\hline
\end{tabular}




\section{Organically cultivated carrots}

The carotene contents were high for carrots grown at both locations, being $7.0 \mathrm{mg} / 100 \mathrm{~g}$ FW at location one and $6.2 \mathrm{mg} / 100 \mathrm{~g} \mathrm{FW}$ at location two. The contents were high also when calculated on the dry weight basis (Table 2 ). When the carotene yields were calculated (Table 2), they were lower in organically cultivated carrots than in the fertilizer experiment.

\section{Discussion}

\section{Genotype}

The main variation in the carotene content of carrots depends on genotype (GABELMAN 1974) and climate (SIMON et al. 1982). In the present study, cv. Nantes Duke Notabene 370 Sv was used; the average carotene content of all treatments and for two years at harvest was $5.2 \mathrm{mg} / 100 \mathrm{~g} \mathrm{FW}$. BAJAJ et al. (1980) studied 23 cultivars of carrot; in their study this variety contained $4.95 \mathrm{mg} \beta$-carotene $/ 100 \mathrm{~g}$ FW. The overall mean of 23 varieties was $5.67 \mathrm{mg} \beta$-carotene/ $100 \mathrm{~g} \mathrm{FW}$ (range $0.85-$ $8.50 \mathrm{mg} / 100 \mathrm{~g} \mathrm{FW})$. Thus in the climatic conditions of southern Finland, this variety can reach the same carotene level as in India.

\section{Weather conditions}

There was a clear difference in the mean carotene content between the two years. The average carotene content for all treatments was $41.2 \%$ higher in 1986 than in 1985 . In 1985 , the mean day temperature and the number of sunshine hours in June and July were lower than in 1986 and lower than the longterm averages (Evers 1988). BARNES (1936) and BANGA et al. (1955) reported that high temperature favours carotene synthesis. HÁRDH (1975) reported that the $\beta$-carotene content of carrots is higher in southern Finland than in northern Finland, a difference that is mainly due to higher temperatures in the southern part of the country. Similar results were also obtained in Norway and Sweden (HÄrdH et al. 1977).

Dragland (1978) reported that low soil moisture content increases the carotene content of carrot roots. Also BANGA \& DE BRUYN (1964) reported that the carotene synthesis increases in dry soil. They concluded that evidently in such case, primary vegetative root growth is suppresed by the low soil moisture content, causing the root to ripen at a smaller root size. This means that protein synthesis is also reduced and it is consuming less carbohydrate compounds. Consequently, most of the carbohydrate compounds available can be used for other consumption processes, such as carotenoid synthesis. BANGA et al. (1963) also studied whether the soil moisture content affected the carotenoid synthesis directly or indirectly by lowering the soil temperature. They found that the soil moisture content had a direct effect. Further BANGA \& DE BRUYN (1964) concluded that an oxygen content under $6 \%$ in the soil atmosphere reduces carotenoid synthesis.

In the present field experiments, in 1985 the precipitation was equal to the long-term averages, and in 1986 the precipitation was heavier than the long-term averages except in June, which was sunny and drier than average (EvERs 1988). In both years there were heavy rains in September; the soil was very moist and perhaps also had a low oxygen content. Precipitation probably does not explain the difference in the carotene contents between years, as in both years the soil remained moist throughout the growing period (except June, 1986). It is more likely that the higher temperature in 1986 is the main reason for the higher carotene contents in 1986 than 1985 .

\section{Developmental stage}

There is general agreement in the literature that the carotenoid content of carrots increases when the plant is ripening (BANGA et al. 1963, Phan \& Hsu 1973, Fritz \& HabBen 1975). Also in the present study, the carotene content increased as the growing season proceeded. 


\section{Fertilization}

Because most of the variation in carotene content is genetically controlled or is dependent on climate, it is obvious that there can be no clear differences between fertilization practices. In more unfavourable year 1985 there was, however, a tendency for the placement of PK fertilizer to increase the carotene content. In future studies it would be intresting to investigate whether it is $\mathrm{P}$ or $\mathrm{K}$ that increases the carotene content and the way in which the nutrient affects the carotene content.

According to the literature, contradictory results have been obtained with increasing nitrogen amounts (FreEMAN \& HaRris 1951,
Southards \& Miller 1962, Habben 1973, Dragland 1978). In the present study, the surplus nitrogen in treatment PK placement with $4 \mathrm{~N}$ fertirrigations did not significantly affect the carotene content as compared to the average of other fertilized treatments, where the $\mathrm{N}$ amount applied was thought to be optimal on the basis of the yield. Thus this study could find no response that depended on the nitrogen amount.

Acknowledgement. I warmly thank Ms. Oili Uusitalo for her excellent technical assistance. I am grateful to Prof. E. Kaukovirta and Prof. A-L. Varis for their valuable comments on the manuscript. The financial support of the Academy of Finland and Kemira Oy is gratefully acknowledged.

\section{References}

Bajas, K.L., Kaur, G. \& Sukhija, B.S. 1980. Chemical composition and some plant characteristics in relation to quality of some promising cultivars of carrot (Daucus carota L.). Qual. Plant. Pl. Foods Hum. Nutr. 30: 97-107.

Banga, O., De Bruyn, J.W. \& Smeets, L. 1955. Selection of carrots for carotene content. II. Subnormal content at low temperature. Euphytica 4: 183-189.

-, De Bruyn, J.W., Van Bennekom, J.L. \& V an KeuLEN, H.A. 1963. Selection of carrots for carotene content. V. The effect of the soil moisture content. Euphytica 12: 137-146.

-, \& DE BruYn, J.W. 1964. Carotenogenesis in carrot roots. Neth. J. Agric. Sci. 12: 204-220.

BARNES, W.C. 1936. Effects of some environmental factors on growth and color of carrots. Cornell Univ. Agric. Exp. Sta. Mem. 186: 1-36.

Dragl.AND, S. 1978. Nitrogen- og vassbehov hos gulrot. Forskn. Förs. Landbr. 29: 139-159.

EVERS, A-M. 1988. Effects of different fertilization practices on the growth, yield and dry matter content of carrot. J. Agric. Sci. Finl. 60: 135-152.

Freeman, J.A. \& Harris, G.H. 1951. The effect of nitrogen, phosphorus, potassium and chlorine on the carotene content of the carrot. Sci. Agric. 31: 207-211.

FrITZ, D. \& HABBen, J. 1975. Determination of ripeness of carrot (Daucus carota L.). Acta Hort. 52: 231-238.

Gabelman, W.H. 1974. The prospects for genetic engineering to improve nutritional values. Nutrition qualities of fresh fruits and vegetables. (Eds. P. White \& N. Selwey). p. 147-155. New York.

Gallagher, P.A. 1966. The effect of potassium on yield

and quality of carrots. Proc. 8. Intern. Potash Inst. Congr. p. 257-263. Brüssel.

HabBen, J. 1973. Einfluss der Stickstoff- und Kaliumdüngung auf Ertrag und Qualităt der Möhre (Daucus carota L.). Landw. Forsch. 26: 156-172.

HÁrdh, J.E. 1975. Der einfluss der umwelt nördlicher breitengrade auf die qualităt der gemüse. Qual. Pl. 25: $43-56$.

Härdh, J.E., Persson, A.R. \& Ottosson, L. 1977. Quality of vegetables cultivated at different latitudes in Scandinavia. Acta Agr. Scand. 27: 81-96.

LANGer, K. 1976. Trennung von Carotinoiden mit Hilfe der HPLC. Dissertation. Friedrich Alexander Universităt. Nürnberg.

NıLsson, T. 1979. Avkastning, lagringsförmåga, kvalitet och kemisk sammansăttning hos morot, vitkål och purjo vid konventionell och organisk gödsling. Inst. Trădg. Vet. Rapp. 7: 3-52.

Phan, C.T. \& Hsu, H. 1973. Physical and chemical changes occurring in the carrot root during growth. Can. J. Pl. Sci. 53: 629-634.

Simon, P.W., Peterson, C.E. \& Lindsay, R.C. 1982. Genotype, soil and climate effects on sensory and objective components of carrot flavor. J. Amer. Soc. Hort. Sci. 107: 644-648.

Southards, C.J. \& Miller, C.H. 1962. A greenhouse study on the macroelement nutrition of the carrot. Proc. Amer. Soc. Hort. Sci. 81: 335-340.

Steel, R.G.D. \& Torrie, J.H. 1980. Principles and procedures of statistics. A biometrical approach. 633 p. 2nd Ed. Tokyo.

Ms received 


\title{
SELOSTUS
}

\section{Eri lannoitustapojen vaikutus porkkanan karoteenipitoisuuteen}

\author{
Aino-Maija Evers \\ Kemira Oy, Espoon tutkimuskeskus, \\ Luoteisrinne 2, 02270 Espoo
}

Eri lannoitusmenetelmien vaikutusta porkkanalajikkeen Nantes Duke Notabene 370 Sv karoteenipitoisuuteen tutkittiin kenttäkokeissa 1985 ja 1986 Kotkaniemen koetilalla Vihdissă. Vertailtavina menetelmină olivat sijoitusja pintalannoitus (ilman kastelua ja kastelun kera), NPKkastelulannoitus ilman peruslannoitusta, NPK-kastelulannoitus, jossa puolet ravinteista annettiin peruslannoituksena, sekä $\mathrm{N}$-kastelulannoitus, jossa $\mathrm{P}$ ja $\mathrm{K}$ annettiin sijoittaen peruslannoituksena. Kokeessa verrattiin myős kerta-annostelua jaksotettuun ravinteiden antoon. Porkkananăytteet karoteenimaaärityksiin kerăttiin sadonkorjuun yhteydessă 1985 sekă 66, 88 ja 121 (sadonkorjuu) päivăn kuluttua kylvőstä 1986. Tulosten analysointiin kảytettiin kontrastianalyysiä, jossa ei verrata yksittäisiă koejäseniă toisiinsa vaan voidaan verrata asiakokonaisuuksia.

Vuonna 1985 sadonkorjuun yhteydessä koejäsenissä, jotka saivat P:n ja K:n sijoittaen peruslannoituksena ja N:n kastelulannoituksena kasvukaudella, oli korkeammat karoteenipitoisuudet kuin pintalannoituksen, kertalannoituksen kastelun kera tai NPK-kastelulannoituksen saaneissa koejăsenissä. Karoteenipitoisuudet olivat myös korkeammat koejäsenissä, jotka saivat P:n ja K:n sijoituslannoituksena, kuin koejäsenissă, joissa P:tă ja K:ta ei annettu sijoituslannoitustekniikalla. Tulokset olivat suuntaa-antavia tasolla $\mathrm{p}=0.1$.

Vuonna 1986 vain ensimmăisellă năytteenottokerralla (66 vrk kylvőstā) lannoitus lisăsi karoteenipitoisuutta $(\mathrm{p}=0.1)$. Lannoitustapa, jossa $\mathrm{P}$ ja $\mathrm{K}$ annettiin sijoittaen keväăllă ja $\mathrm{N}$ kastelulannoituksena kasvukaudella, lisăsi suuntaa-antavasti $(\mathrm{p}=0.1)$ karoteenipitoisuutta verrattuna sijoituslannoitukseen, yhteen antokertaan ja kasteltuun yhteen antokertaan.

Kaikkien koejäsenten karoteenipitoisuus nousi kasvukauden edetessă. Vuoden săätekijöillă oli selvă vaikutus karoteenipitoisuuksiin. 